\title{
Проблемы противодействия проявмениям нарушения миграционного законодательства как современной угрозе безопасности государства
}

\section{И. Ю. САМОХВАЛОВ}

Арзамасский филиал Национального исследовательского Нижегородского государственного университета им. Н. И. Лобачевского, г. Арзамас, Российская Федерация

ORCID: https://orcid.org/0000-0001-7932-6238, e-mail: herrysam@mail.ru

Р е ферат

Введение: в статье рассмотрены вопросы, характеризующие общее состояние миграционной обстановки в стране, причины и условия существования преступности в сфере миграции, обозначены особенности государственного противодействия миграционным правонарушениям. Цель: путем анализа состояния миграционной действительности обозначить проблемы существования и противодействия миграционным правонарушениям на современном этапе развития общества. Методы: общенаучный диалектический метод познания, сравнительно-правовой, эмпирические методы описания, интерпретации, метод толкования правовых норм. Результаты: анализ проявлений миграционной преступности дал возможность определить ее признаки, внутреннее содержание, сущность, виды, объективность существования, что позволялило предложить пути противодействия настоящему состоянию данного вида преступности. Выводы: при изучении состояния противодействия миграционным правонарушениям предложен ряд мер, способных изменить существующую ситуацию с преступностью в миграционной сфере. Среди них: усиление учета мигрантов при прохождении государственной границы; повышение ответственности недобросовестного работодателя, предоставляющего работу мигрантам в нарушение действующего законодательства; введение обязательной оплаты недобросовестным работодателем расходов, связанных с выдворением обнаруженных незаконно находящихся мигрантов; усиление ответственности работодателя; ужесточение санкций существующего законодательства за представление мигрантами подложных документов для регистрации и за регистрацию по ним; укрепление функциональной деятельности структур ФМС России путем наделения правом на выполнение оперативно-розыскной деятельности и взаимодействие с оперативными аппаратами правоохранительных органов, осуществляющими такую деятельность; определение приоритета наружных и оперативных служб на выявления фактов незаконного пребывания мигрантов на территории мегаполиса; создание единого кодифицированного акта - миграционного кодекса, регулирующего правовые отношения, возникающие в миграционной сфере.

К люче в ы е с ло в а : миграционная преступность; трудовая миграция; неконтролируемая миграция трудовых ресурсов; правовой статус; виктимизация; миграционные диаспоры.

12.00.08 - Уголовное право и криминология; уголовно-исполнительное право.

Для цитирования: Самохвалов И. Ю. Проблемы противодействия проявлениям нарушения миграционного законодательства как современной угрозе безопасности государства. Пенитенциарная наука, 2021, т. 15, № 1 (53), с. 43-54. DOI 10.46741/2686-9764-2021-15-1-43-54.

\section{Countering Migration Legislation Violations as a Modern Threat to National Security}

\section{IGOR' YU. SAMOKHVALOV}

Arzamas Branch of National Research Lobachevsky State University of Nizhni Novgorod, Arzamas, Russian Federation ORCID: https://orcid.org/0000-0001-7932-6238, e-mail: herrysam@mail.ru 
A bstract. Introduction: the paper investigates migration situation in the country, reasons and prerequisites for migration-related crime, and identifies features of state prevention of migration offenses. Aim: by analyzing current migration situation, to identify problems in the field of migration-related offenses and how to counteract them at the current stage of society development. Methods: general scientific dialectical method of cognition, comparative legal method, empirical methods of description and interpretation; method of interpretation of legal norms. Results: having analyzed manifestations of migration-related crime we determine its signs, internal content, essence, types, and objectivity of existence; this allows us to put forward ways to counteract the current state of this type of crime. Conclusions: when studying how migration offenses are counteracted, we propose a number of measures that can change the existing crime situation in the migration sphere. Among them: strengthening the registration of migrants when passing the state border; increasing the responsibility of an unscrupulous employer who provides work to migrants in violation of current legislation, obliging unscrupulous employers to cover expenses related to the expulsion of illegally located migrants, strengthening the responsibility of the employer; tightening the sanctions of existing legislation for submission of false documents for registration by migrants and for registration based on false documents; strengthening the functional activities of the Federal Migration Service by granting it the right to perform intelligence-gathering activities and interaction with operative units of law enforcement agencies engaged in such activities; determining the priority of external and operative services to identify the facts of illegal stay of migrants in the territory of the metropolis; establishment of a single codified act - the migration code, regulating legal relations arising in the migration sphere.

Keywords: migration-related crime; labor migration; uncontrolled migration of labor resources; legal status; victimization; migration diasporas.

12.00.08 - Criminal law and criminology; penal law.

For c it ation: Samokhvalov I.Yu. Countering migration legislation violations as a modern threat to national security. Penitentiary Science, 2021, vol. 15, no. 1 (53), pp. $43-$ 54. DOI 10.46741/2686-9764-2021-15-1-43-54.

\section{Введение}

Внешняя трудовая миграция как общественное явление вошла в жизнь нашей страны и в настоящее время приобретает глобальные масштабы, затрагивая многие отрасли существования социума. Общество, с одной стороны, не может отказаться от трудовой миграции по экономическим мотивам, а с другой - наблюдается неготовность к решению ряда проблем в связи с отсутствием или недостаточной активностью законодателя в этой отрасли правоотношений.

Современная геополитическая обстановка, интенсификация миграционных процессов, а также стабильно высокие показатели преступности иностранных граждан вызывают потребность в правовом регулировании исполнения и отбывания уголовных наказаний и иных мер уголовно-правового характера данных категорий преступников. Осужденные-мигранты обладают специальным правовым статусом, на что неоднократно обращалось внимание в пенитенциарной литературе.

Так, согласно ст. 10 УИК РФ, Российская Федерация уважает и охраняет права, свободы и законные интересы осужденных, обеспечивает законность применения средств их исправления, их правовую защиту и личную безопасность при исполнении наказаний. Осужденные иностранные граждане и лица без гражданства пользуются правами и несут обязанности, которые установлены международными договорами Российской Федерации, законодательством Российской Федерации о правовом положении иностранных граждан и лиц без гражданства с изъятиями и ограничениями, предусмотренными уголовным, уголовноисполнительным и иным законодательством Российской Федерации.

Статистические данные свидетельствуют об уменьшении количества преступлений, совершенных иностранными гражданами и лицами без гражданства за последние годы: в 2019 г. иностранными гражданами и лицами без гражданства было совершено 20165 преступлений, в том числе 16196 гражданами государств - участников СНГ; в 2018 г. - 23164 преступления, в том числе -16 777 гражданами государств - участников СНГ; в 2017 г. - 25580 преступлений, в том числе - 18222 гражданами государств участников СНГ [13].

В 2016 г. иностранными гражданами и лицами без гражданства было совершено 
37,8 тыс. преступлений, что на 7,6 \% меньше, чем за аналогичный период 2015 г., в том числе гражданами государств - участников СНГ - 33,2 тыс. (для сравнения: за январьноябрь 2015 г. иностранными гражданами и лицами без гражданства на территории Российской Федерации было совершено 42,8 тыс. преступлений, что на 3,7 \% больше, чем за аналогичный период 2014 г., в том числе гражданами государств - участников СНГ 37,2 тыс. преступлений $(+4,4 \%)$, их удельный вес составил $87 \%$; за январь-ноябрь 2013 г. иностранными гражданами и лицами без гражданства на территории Российской Федерации было совершено 43,3 тыс. преступлений, что на 10,2 \% больше, чем за январь-ноябрь 2012 г., в том числе гражданами государств - участников СНГ - 37,2 тыс. преступлений (+8 \%), их удельный вес составил $86 \%$ ) [13].

Проблемы противодействия проявлениям нарушения миграционного законодательства как современной угрозе безопасности государства

Изменения, происходящие в мировом экономическом сообществе, где наблюдается объективная зависимость государств от присутствия значительного количества трудовых мигрантов, требуют выработки комплекса сбалансированных мер регулирования миграционных потоков. Современная действительность вызывает необходимость приведения существующей ситуации с незаконной миграцией в соответствие правовым нормам и стандартам. С одной стороны, мигранты выступают как неотъемлемая составляющая и движущая сила экономического подъема государства, а с другой - присутствует комплекс нерешенных проблем, связанных с обеспечением безопасности страны от миграционной экспансии. Достаточно высоки риски ухудшения криминальной ситуации, появления и укоренения религиозного и этнического экстремизма. С приездом дешевой рабочей силы из республик Средней Азии в регионы проникает и исламский фундаментализм, тесно связанный с экстремизмом и терроризмом. О том, что этой проблемой обеспокоено большое число развитых государств, которые подвергаются миграционной экспансии, говорит постоянная выработка мер В рамках национально-государственной политики, где используется симбиоз как добровольно договорной, так и репрессивной реакции правовых государственных структур по регулированию циркулирующих миграционных потоков. Международная конференция ООН по народонаселению и развитию 1994 г. определила, что «незарегистрированные или нелегальные мигранты - это лица, которые не удовлетворяют установленным принимающей стороной требованиям в отношении въезда, пребывания или экономической деятельности». Кроме того, «в связи с продолжающимся увеличением численности населения ожидается, что масштабы незарегистрированной или нелегальной миграции будут возрастать» [5, с. 76]. По мнению иностранных наблюдателей, нелегальная миграция становится альтернативой для тех мигрантов, которые не могут пройти жесткие критерии отбора, и тех, для кого нелегальная миграция менее затратна. В странах, где возможности легального въезда или пребывания значительно ограничены (в том числе страны ЕС), использование механизмов нелегальной миграции для большинства потенциальных мигрантов становится практически единственным способом переезда [8]. Процесс глобализации, затрагивающий все стороны общественной жизни, не может пройти мимо незаконной миграции, которая приспосабливается к исторической формации, определяя свое место в разряде проблем международного масштаба. Опрос жителей Европейского Союза осенью 2012 г. показал, что иммиграция, в том числе нелегальная, рассматривалась ими в числе пяти наиболее важных проблем, с которыми сталкивается ЕС в настоящее время [16, с. 12]. По данным международных исследований, жители развитых стран связывают приток мигрантов с ухудшением условий жизни коренного населения, ростом преступности, угрозами международного терроризма, увеличением нагрузки на систему социальной помощи и другими негативными явлениями [15, с. 2].

Понятие «миграция» и в законодательстве, и в повседневной жизни толкуется достаточно широко: это постоянное перемещение отдельных лиц либо их групп из одного места в другое [1, с. 93], при этом изменяется и их правовое состояние.

В соответствии с Федеральным законом от 15.08.1996 № 114-Ф3 «О порядке выезда из Российской Федерации и въезда в Российскую Федерацию» незаконный въезд трактуется как нарушение установленных правил въезда, где виновное лицо умышленно нарушает установленные законом про- 
цедуры оформления документов [2, с. 51]. Федеральный закон от 25.07.2002 № 115-Ф3 «О правовом положении иностранных граждан в Российской Федерации» рассматривает незаконную занятость как трудовую деятельность иностранцев, осуществляемую ими в нарушение закона, регламентирующего четкую процедуру оформления правового статуса мигранта [4, с. 231].

По мнению ученых, международная или внешняя миграция населения - это непрерывный процесс, характерный для большинства стран мира. Цель миграции - перемещение людей и их обустройство на более благополучных, выгодных и экономически перспективных территориях. Под благополучием понимается относительная стабильность и безопасность (отсутствие вооруженных межнациональных конфликтов, возможность найти посильную и оплачиваемую работу, пригодный для жизни природный климат, более или менее экологически сбалансированное хозяйствование, стандартный минимум мер социальной защиты и т. п.) [7, с. 12].

Существующий дисбаланс в управлении миграционными процессами, который должен предусматривать присутствие необходимого и вместе с тем достаточного контингента приезжих граждан на территории конкретного мегаполиса, влечет наряду с экономическими, социальными, демографическими и криминальные последствия. Неурегулированное положение в области миграции может быть связано с различными моментами, такими как отъезд, транзит, въезд и возвращение, причем и нарушения законности могут совершаться как в отношении мигрантов, так и самими мигрантами [6, с. 11]. В программных выступлениях Правительства России, в частности Стратегии национальной безопасности Российской Федерации до 2020 г., обозначены задачи по корректировке государственной миграционной политики применительно к внешней трудовой миграции. Наряду с целями и задачами основными направлениями миграционной политики утверждены механизмы ее реализации в ракурсе интеграционных процессов, протекающих на территории государств - участников Таможенного союза.

В соответствии с действующим законодательством о введении системы квотирования привлекаемой иностранной рабочей силы установлены условия и порядок вы- дачи разрешений на привлечение рабочей силы, а также подтверждений иностранным гражданам права трудовой деятельности на территории Российской Федерации. Указ Президента Российской Федерации от 16.12.1993 № 2146 (с последующими изменениями и дополнениями) регламентировал специальный порядок оформления трудовых отношений для иностранных граждан, въехавших в Российскую Федерацию с целью осуществления профессиональной деятельности. Необходимость подтверждения права трудовой деятельности, выданное гражданину на основании полученного работодателем разрешения, - основное условие возможности работы по найму на территории Российской Федерации. Нарушители требований подлежат выдворению за пределы Российской Федерации за счет средств работодателя.

В регионах наблюдается ответственное отношение административного аппарата к квотам на трудовые ресурсы. Количество заявок работодателей на привлечение иностранных работников, например, в Оренбургской области составило свыше 13 тыс. чел. в год, процесс рассмотрения заявок носит конструктивный характер. Однако административная система квотирования миграционных потоков рабочей силы несовершенна, имеет слишком затянутые сроки рассмотрения, но вместе с тем бесконтрольность этих процессов может вызвать противодействие со стороны местного населения.

В системе миграционного регулирования наблюдаются процессы, негативно влияющие на состояние рынка труда. Потребность в работниках, заявленная работодателями, значительно превышает реальные возможности их использования. Вместе с тем ожидания работников не соответствуют предложениям работодателей, что в свою очередь избирательно воздействует на выбор трудового потенциала. Существующий рынок труда в регионах страны деформирует массовая и неконтролируемая миграция трудовых ресурсов, приводящая к множеству социальных проблем и последствий. Причем деформация приводит к тому, что в одних регионах, например в Санкт-Петербурге, Калининградской области, наблюдается активный приток мигрантов, в то время как в других, в частности Новгородской, Псковской, Мурманской областях, происходит обратный процесс. 
Не секрет, что во многих ставших независимыми государствами бывших республиках СССР за прошедшие годы экономика ослабла окончательно. Так, по данным депутатов Киргизского парламента (фракция социал-демократов), за годы независимости ни одно производство не было реанимировано, ни один завод не начал работать благодаря усилиям правительства, что вызвало отток граждан из страны. Вместе с тем в бывших республиках наблюдается негативное отношение к России в плане оказания помощи для подъема экономики. По мнению парламентариев Киргизии, Россия, выступая ядром в процессе интеграции, должна взять большую часть политической и экономической нагрузки. Россия добровольно уходит из регионов, обещает строить ГЭС в Киргизии на протяжении многих лет, но сама этого не делает и другим не дает. Китай же строит заводы с большими мощностями, железную дорогу, что позволит заниматься экспортом и реэкспортом. Что касается русского языка, то он является официальным языком в Киргизии. По мнению парламентариев, есть предложение ввести двойное гражданство между Киргизией и Россией, что будет способствовать широкой интеграции народов и значительно сократит отток граждан Киргизии из страны на заработки в Россию.

Так, по сведениям правительства Киргизии, на территории Российской Федерации осуществляют трудовую деятельность около 250-270 тыс. граждан Киргизии, ежегодно растет количество принятия ими российского гражданства. Согласно официальной статистике трудовые мигранты каждый год переводят на родину до 1,5 млрд долларов, по неофициальным данным - в два раза больше. Вместе с тем в ряде регионов наблюдаются факты прямой дискриминации местного населения. Так, например, выявлен факт, ставший известным в правительстве, об объявленной заявке работодателя ООО «Агрофирма Северная» на 200 трудовых мигрантов по профессии операторов птицеводства для работы на Кировоградской птицефабрике. Проблему дискриминации озвучили представители профсоюзной организации в связи с высоким уровнем безработицы среди местных жителей, где кадровый голод в связи с увольнением местных специалистов решается за счет мигрантов. Данный вопрос был разрешен местными властями. Межведомственная комиссия, изучив заявки недобросовестных заявителей и работодателей, нарушающих права граждан, вдвое сократила миграционные квоты. Наблюдаются злоупотребления и в противоположную сторону. Так, при формировании квот на мигрантов должна учитываться адекватная оценка потребностей региона. К примеру, по результатам областного заседания в Свердловской области из квот на привлечение мигрантов была полностью исключена профессия «охранник». Что касается выделения квот на иностранных работников строительных профессий, то выявлены факты, когда работодатели умышленно заявляют заработную плату на уровне гораздо ниже предусмотренного федеральным соглашением по строительной отрасли, очевидно, исходя из личной заинтересованности или лоббирования интересов определенной группы людей.

Осторожная оценка перспектив миграционной ситуации в средней полосе России свидетельствует о возможном увеличении миграционных потоков, которое может вызвать осложнения на рынке труда, нарушения социально бытовой сферы мегаполисов и, самое опасное, рост уровня криминогенности.

Вместе с тем анализ законодательства, в частности вступивших в силу федеральных законов «О беженцах», «О вынужденных переселенцах», факт ослабления контроля за миграционными процессами в свете исполнения постановления Конституционного Суда Российской Федерации от 02.02.1998 «По делу о проверке конституционности пунктов 10, 12 и 21 действующих Правил регистрации и снятия граждан Российской Федерации с регистрационного учета по месту пребывания и месту жительства в пределах Российской Федерации от 17 июля 1995 года № 713» свидетельствуют о возникновении ситуации, при которой был отменен и вышел из административной практики правоохранительных структур ряд инструментов административно-правового воздействия, сдерживающих негативные тенденции в миграционной сфере. Здесь необходимо упомянуть Федеральный закон от 25.06.1993 № 5242-1 «О праве граждан Российской Федерации на свободу передвижения, выбор места пребывания и жительства в пределах Российской Федерации», который нанес значительный вред отменой порядка регистрации по месту пребывания [10, с. 126]. 
Процедура обнаружения незаконного пребывания на территории мегаполисов неучтенных мигрантов состоит в анализе результатов обработки миграционных карт, когда возможно установить количество въехавших иностранных граждан, часть из которых согласно заявленной причине прибытия обозначила осуществление трудовой деятельности. Однако если сопоставить эту цифру с фактически выданными разрешениями на работу, то выявляется значительное количество работавших незаконно. Такая ситуация в корне противоречит Федеральной миграционной программе, определяющей направления государственной политики в области привлечения и использования в Российской Федерации иностранной рабочей силы, к которым относятся: удовлетворение потребностей российского рынка труда в необходимой рабочей силе, формирование рациональной и сбалансированной структуры этого рынка, обеспечение на национальном рынке труда приоритетного права российских граждан на трудоустройство, а также предотвращение нелегальной трудовой миграции [12, с. 154].

Указом Президента Российской Федерации от 19.07.2004 № 928 были объединены миграционная и паспортно-визовая службы МВД России в Федеральную миграционную службу, а также определены основные задачи последней:

1) производство по делам о гражданстве Российской Федерации, оформление и выдача основных документов, удостоверяющих личность гражданина Российской Федерации;

2) осуществление регистрационного учета граждан Российской Федерации по месту пребывания и по месту жительства в пределах Российской Федерации, контроля за соблюдением гражданами и должностными лицами правил регистрации и снятия с регистрационного учета граждан Российской Федерации;

3) оформление и выдача иностранным гражданам и лицам без гражданства документов для въезда в Российскую Федерацию, для проживания и временного пребывания в Российской Федерации;

4) осуществление контроля за соблюдением иностранными гражданами и лицами без гражданства установленных правил проживания и временного пребывания в Российской Федерации;

5) разработка и реализация во взаимодействии с иными государственными орга- нами мер по предупреждению и пресечению незаконной миграции;

6) исполнение законодательства Российской Федерации по вопросам беженцев и вынужденных переселенцев, участие в установленном порядке в предоставлении политического убежища иностранным гражданам и лицам без гражданства;

7) осуществление в соответствии с законодательством Российской Федерации контроля и надзора в сфере внешней трудовой миграции, привлечения иностранных работников в Российскую Федерацию и трудоустройства граждан Российской Федерации за пределами Российской Федерации;

8) управление территориальными органами ФМС России, ее представительствами за рубежом и иными организациями и подразделениями, созданными для решения возложенных на ФМС России задач.

Разнообразие преступлений, совершаемых в миграционной сфере, требует своевременной реакции правоохранительных органов. Взять, к примеру, анализ ситуации по прибывающим иностранцам. Как правило, до 80 \% прибывающих по адресу предполагаемого места жительства иностранцев зарегистрированными не значатся, что значительно затрудняет контроль за данной категорией лиц и говорит о том, что данные граждане находятся на территории мегаполиса на нелегальном положении.

Нелегальное проживание мигранта в мегаполисе, то есть нахождение человека вне правового поля, без соблюдения алгоритмов законной регистрации, способствует процессу его виктимизации. Вышеназванный контингент, с одной стороны, является центром повышенного внимания - контроля со стороны государственных органов, выполняющих правоохранительные функции исполнения миграционного законодательства, с другой - становится объектом посягательства криминальных структур, использующих факт незаконного пребывания в целях личного обогащения. Организованные криминальные структуры имеют возможность вести свой бизнес по нелегальному распределению и продаже рабочей силы, используя вымогательство, захват и удержание личных документов мигрантов. Мигранты становятся заложниками криминальных разборок между конкурирующими группировками, где используется оружие. Имея значительные доходы, криминал владеет схемами ухода от ответственности, 
обладает коррупционными связями в различных эшелонах власти. Между трудовыми мигрантами и местным населением отсутствует социальное взаимодействие. Существование в качестве замкнутой общины минимизирует возможности полноценной интеграции мигрантов и принимающего общества, а отсутствие взаимного культурного обмена не способствует преодолению имеющихся стереотипов негативного взаимного восприятия. Значительную роль в этой ситуации играют межнациональные связи, а существующая национальная закрытость диаспор значительно усложняет проникновение в них, получение своевременной оперативной информации, что не способствует своевременному противодействию этому виду преступности.

Нелегальное присутствие в стране делает мигранта жертвой произвола работодателя, который, используя его труд вне рамок трудового законодательства, по своему усмотрению устанавливает продолжительность рабочего дня (не менее 10-12 ч), несправедливо регулирует оплату труда, минимизирует расходы на охрану труда, здоровья и санитарных норм работающих. О трудовом контракте многие даже не слышали, трудовые отношения оформляются посредством устной договоренности. Если говорить об условиях проживания, они настолько минимизированы, что о соблюдении элементарных санитарных норм говорить не приходится, как правило, рабочие живут там, где трудятся. Что касается регистрационного учета, то федеральный закон «О праве граждан Российской Федерации на свободу передвижения, выбор места пребывания и жительства в пределах Российской Федерации» под фиктивной регистрацией по месту пребывания или по месту жительства понимает регистрацию, осуществленную с использованием заведомо подложных документов, либо без намерения пребывать в этом помещении, либо регистрацию без намерения собственника жилого помещения предоставить его для этих целей. Во всех случаях это умышленные действия со стороны виновных. Таким образом, факт отсутствия регистрации порождает преступление, криминализируемое законодателем по ст. 322.2 УК РФ.

Управления внутренних дел фиксируют увеличение количества зарегистрированных уголовных дел в отношении иностранных граждан. Спектр преступлений доста- точно широк: это убийства, умышленное причинение тяжкого вреда здоровью, разбои, вымогательства, грабежи, кражи и мошенничество [3, с. 6]. Все это говорит о виктимности данной категории лиц. Вместе с тем необходимо отметить высокую латентность преступлений в отношении приезжих. Здесь ярко проявляются и естественная, и искусственная латентность. Как правило, последняя выражается в сознательно скрываемых правоохранительными органами от учета и последующего правового реагирования на преступления по причине слабого, а порой и полного отсутствия оперативного прикрытия, невозможности получения необходимой информации, сложности проникновения в миграционные диаспоры. Это говорит о снижении профессионального уровня сотрудников правоохранительных органов, отсутствии согласованности работы наружных служб ОВД и следственно-оперативных аппаратов.

Миграционная преступность отличается специфическими способами и методикой раскрытия и предупреждения. В первую очередь это связано с наличием следующих обстоятельств: временными рамками пребывания (как правило, кратковременного), специфики субъекта преступления, попыток скрыться после совершения преступления; активная поддержка диаспоры, проявляющаяся в оказании помощи - от финансовой до укрывательства от правоохранительных органов; закрытость миграционных сообществ, основанных, как правило, на родственных отношениях или отношениях землячества; наличие языкового барьера, который усложняет оперативное проникновение в сообщество и делает невозможным реализацию упреждающих мер.

Оперативные сводки правоохранительных структур пестрят сообщениями о конфликтах, перерастающих в преступления, где мигранты играют ключевую роль, а выявленные в процессе расследования обстоятельства совершения преступлений говорят о правовых пробелах и недостатках существующего законодательства в миграционной сфере. Анализируя происшествия с участием мигрантов, где фигурируют убийства или насильственные действия в отношении местных жителей, можно обнаружить, что основной причиной нигилистического отношения к закону мигрантов является недостаточное противодействие миграционной преступности со стороны правоохранитель- 
ных органов. Конфликтные ситуации с участием мигрантов не возникают на ровном месте и развиваются, как правило, по одному и тому же сценарию. Так, для осуществления подъема отрасли или конкретного производства в мегаполисе возникает потребность в использовании определенного количества мигрантов, которые сначала планово и законно, а затем хаотично и в обход законодательства наполняют предприятие или производственный сектор. Происходит постепенный захват и вытеснение из этого сектора представителей местного населения, вплоть до замены руководства. Эти процессы происходят на глазах правоохранительных структур, которые отстранились от контроля ситуации возникновения и разрастания диаспоры. Ведь не секрет, что гораздо легче управлять контингентом мигрантов, имея авторитета из их числа, который своими силами, влиянием, а порой и специфическими методами и способами будет осуществлять регулирование внутри диаспоры. До определенного момента этот контингент относительно управляем, постепенно диаспора превращается в маленькое государство, где правят законы, установленные мигрантами-авторитетами с явным националистическим уклоном. Нежелание ассимилировать, подчиняться законам страны пребывания, подогретое не всегда комфортными условиями проживания, толкает мигрантов на протест. Объединенные общей трудовой деятельностью, оторванностью от постоянного места жительства, сплоченные проблемами существования и быта, они начинают активно противодействовать установленному порядку, укладу жизни, традициям местного населения.

Нарастающие, как снежный ком, противоречия выливаются в преступные проявления, связанные с насильственными действиями. Например, прогремевшее на всю страну убийство гражданином Азербайджана в районе Бирюлево Западное г. Москвы местного жителя в октябре 2013 г., убийство жителя в г. «А» Нижегородской области мигрантом и т. д. Возникшие после этих случаев массовые беспорядки, поддержанные активными действиями местной молодежи, потребовали значительных усилий городских администраций, правоохранительных структур, спецподразделений для предотвращения хулиганских проявлений. В процессе расследования и анализа ситуации в Бирюлево правоохранительными органами были выявлены более 200 нелегальных мигрантов. Подобная картина наблюдалась и в г. «А», где значительное число приезжих с Кавказа и из Азии пребывали в городе, нарушая миграционное законодательство. Результаты расследования подтверждают, что работа по учету мигрантов поставлена настолько неудовлетворительно, что при чрезвычайных обстоятельствах невозможно установить их точное количество, место проживания, занятость.

По данным пресс-службы Пограничного управления ФСБ России, статистика правонарушений в среднем за полугодие в пунктах пропуска через границу в Оренбургской области выглядит следующим образом: до 50 попыток пересечения границы по поддельным документам, более 3 тыс. с документами, требующими доработки и исправления. Также увеличивается число пресечения попыток въезда лицам, присутствие которых на территории России запрещено. За правонарушения, связанные с защитой Государственной границы Российской Федерации, наложено административных штрафов на сумму свыше 750 тыс. руб., возбуждено более 80 уголовных дел по ч. 1 ст. 322 и ч. 3 ст. 327 УК РФ.

Систематически органами прокуратуры выявляются факты заключения фиктивных браков с гражданами иностранных государств с целью дальнейшего получения в упрощенном порядке разрешения на временное проживание на территории Российской Федерации. Фабула этих дел примерно одинакова: гражданка иностранного государства выплачивает «супругу» вознаграждение (около 8-10 тыс. руб.), составляются необходимые документы, брак регистрируется, после чего отношения прекращаются. Как выясняет прокуратура, с момента заключения брака лжесупруги совместно не проживают, общих детей не имеют, совместное хозяйство не ведут. Результатом рассмотрения гражданского дела является решение об аннулировании записи акта гражданского состояния. Соответственно, последствия данных действий регламентируются федеральным законом «О правовом положении иностранных граждан в Российской Федерации», когда разрешение на временное проживание иностранному гражданину аннулируется в случае признания судом заключения брака недействительным. Впоследствии у иностранного гражданина прекращается 
право на временное проживание, и он обязан покинуть территорию России в течение 15 дней.

В структуре миграционной преступности значительное место занимают действия с поддельными документами. Однако активного применения санкций за данное преступление, к сожалению, не происходит. Что касается ст. 327 УК РФ, то здесь ответственность распространяется на преступные посягательства против установленного порядка управления и отсутствует обеспечение уголовно-правовой охраны личных документов. Ряд авторов полагают, что «основой наказуемости подобных деяний являются вред и опасность, возникающие для общественных, государственных или частных интересов, связанных с обращением документов» [11, с. 10]. Применяемая в контексте к миграционным правонарушениям данная статья УК РФ наряду с интересами управления, как правило, затрагивает и экономические интересы государства. Вместе с тем необходимо определить, что исполнение объективной стороны ст. 327 УК РФ напрямую связано со ст. 292 УК РФ «Служебный подлог», который посягает сразу на два объекта: официальный документооборот и интересы службы в органах государственной власти и службы в органах местного самоуправления. В данном случае присутствует цель - скрыть другое преступление или облегчить его совершение. Необходимость самостоятельной квалификации изготовления поддельного документа, который в дальнейшем будет использован для реализации тех или иных целей преступника, подвергается дискуссии. Так, по мнению ряда ученых, все содеянное следует квалифицировать лишь один раз, без совокупности с нормой об изготовлении поддельного документа: подлог, подделка и использование подложных документов, штампов и т. д. рассматриваются в качестве способа письменного обмана в преступлениях большей общественной опасности, а не совокупности подлога и соответствующего деяния [9, с. 31]. В настоящее время наблюдается недостаточное внимание судов к противодействию преступлениям, предусмотренным ст. 327 УК РФ, подтверждением чему является реакция судейского сообщества: реальное лишение свободы назначается лишь по совокупности с другими преступлениями (чаще всего с мошенничеством, присвоением или растратой).
Таким образом, суды не признают достаточно высокой степень общественной опасности простой подделки документов.

При сравнении практического применения ст. 292 и ст. 327 УК РФ остаются неясны причины, подтолкнувшие законодателя в ст. 292 УК РФ ограничить ответственность за служебный подлог корыстной или иной личной заинтересованностью. В действиях государственного служащего, осуществляющего внесение в официальные документы заведомо ложных сведений, а равно внесение в них исправлений, искажающих их действительное содержание, всегда присутствует не только данный мотив. Отсутствует упоминание о мотиве в ст. 327 УК РФ, при котором фактически государственные и муниципальные служащие, нарушая свои служебные обязанности, находятся в более привилегированном положении в сравнении с обычными лицами, причем нередко возникают определенные сложности при разграничении служебного подлога и злоупотребления должностными полномочиями ст. 285 УК РФ. По нашему мнению, использование подложногодокумента является необходимой составляющей обмана или злоупотребления доверием как одним из способов мошенничества, контрабанды, а также и других преступлений, связанных с оформлением документов мигрантами. Именно этими обстоятельствами можно объяснить недостаточное уголовно-правовое и криминологическое воздействие ст. 292 и ст. 327 УК РФ в сфере миграционной преступности.

Негативную роль во взаимопонимании представителей властных структур и мигрантов играет языковой барьер. В настоящее время мигранты обладают более низким уровнем образования, знания русского языка и профессионально-квалификационной подготовки. В свете исполнения подписанного Президентом России указа по введению обязательного экзамена по русскому языку, истории России, основам законодательства Российской Федерации для трудящихся-мигрантов в Киргизии, например, предпринимаются реальные действия, направленные на возможность ассимиляции трудовых мигрантов к жизни в России. Для этого активно открываются центры тестирования на знание русского языка, один из которых функционирует на базе киргизскороссийского Славянского университета. Результативность проводимой работы будет достигнута при синхронной деятельности 
обеих стран. Необходимость объединения усилий важна и для признания в Российской Федерации юридической силы тестирования на знание русского языка на территории Киргизии. Этот процесс потребует активной деятельности специалистов по русскому языку, литературе, истории и, конечно, праву. Правительство Киргизии считает перспективным создание учебных центров, способных дать требуемые знания и навыки желающим работать в России гражданам Киргизии. Взвешенный детальный подход к этой проблеме позволит определить разный уровень владения русским языком для использования в разных сферах трудовой активности мигрантов. Также обсуждается вопрос о направлении в Киргизию специалистов для обучения местных жителей русскому языку.

По нашему мнению, назрела необходимость введения в стране государственного института Уполномоченного по правам мигрантов, что позволит подготовить основу для решения указанных проблем, сократить нарушения прав человека со стороны государственных органов, осуществлять постоянный мониторинг материального положения мигрантов, их настроений, повысить правовую грамотность, а также способствовать их интеграции в социум Российского государства.

Введение института уполномоченного будет способствовать как предупреждению преступности в отношении мигрантов, так и повышению эффективности соблюдения прав и законных интересов указанной категории лиц при совершении ими преступлений и правонарушений. Так, до настоящего времени четко не урегулированы в уголовно-исполнительном законодательстве такие вопросы, как детализация и правовое закрепление в УИК РФ статуса переводчика и условия предоставления его услуг, легализация и особенности правового положения мигранта, вовлеченного в уголовно-исполнительные отношения. Кроме того, все чаще в научной литературе звучат предложения о целесообразности создания специализированных исправительных учреждений для иностранных граждан и лиц без гражданства [14, с. 194], разработке и реализации которых будет способствовать создание института Уполномоченного по правам мигрантов.

K наиболее общим причинам незаконной миграции можно отнести:
- недостаточно отрегулированную информационную базу потребностей мегаполиса (отсутствие государственного заказа) на миграционный контингент с учетом баланса интересов местного населения и мигрантов, технологические недостатки квотирования трудовых ресурсов на уровне региона;

- отсутствие цивилизованной формы организованного набора иностранных работников с учетом квалификации, знания языкового минимума, позволяющего комфортно себя чувствовать в стране пребывания;

- правовые пробелы и несовершенство действующего законодательства в миграционной сфере, достижения правового эффекта действия уголовного законодательства (ст. 292, 327, 285 УК РФ), отсутствие взаимодействия в работе контролирующих и правоохранительных структур регионального и местного уровней;

- неподготовленность и неразвитость миграционной инфраструктуры, не дающей мигрантам чувствовать себя комфортно и в безопасности, что в свою очередь создает возможность существования теневых посредников, оформляющих мигрантам фиктивные разрешения на работу, медицинские справки, документы о постановке на регистрационный учет с использованием так называемых «резиновых квартир».

\section{Заключение}

Несмотря на проводимые совместные мероприятия правоохранительных структур по противодействию совершению преступлений в сфере миграции, выполнение основных положений миграционной политики страны находится на недостаточно высоком уровне, что позволяет процветать теневому бизнесу на мигрантах.

Такое положение требует принятия неотложных мер, среди которых, по нашему мнению, необходимы следующие:

1. Введение системы усиленного учета мигрантов на государственной границе по правилу «контролируемое прибытие, контролируемый срок пребывания, контролируемое убытие из страны». Необходимо внедрить систему электронного дактилоскопического сканирования отпечатков пальцев либо сетчатки глаза мигрантов, что поможет предотвратить въезд нарушивших миграционное административное законодательство граждан. 
2. Ужесточение действующего законодательства, в частности усиление ответственности за предоставление подложных документов и регистрацию по ним, эффективное применение ст. 292, 285, 327 УК РФ в отношении должностных лиц.

3. Повышение ответственности недобросовестного работодателя, незаконно предоставляющего работу мигрантам, вплоть до обязательной оплаты расходов, связанных с выдворением незаконно находящихся мигрантов.

4. Укрепление функциональной деятельности структур ФМС России путем предоставления права на осуществление оперативно-розыскной деятельности и взаимодействие с оперативными аппаратами правоохранительной системы, определение приоритета наружных и оперативных служб в выявлении фактов незаконного пребывания мигрантов на территории мегаполиса, улучшение показателей по данному направлению в отчетах МВД России и других правоохранительных структур.

5. Создание единого кодифицированного акта - миграционного кодекса, регулирующего правовые отношения, возникающие в миграционной сфере.

6. Введение в стране государственного института Уполномоченного по правам мигрантов, что позволит подготовить базу для решения многочисленных проблем мигрантов на государственном уровне.

\section{СПИСОК ЛИТЕРАТУРЫ}

1. Бобырев, В. В. Актуальные проблемы правового обеспечения противодействия незаконной миграции / В. В. Бобырев // Право и экономика. - 2008. - № 1. - С. 92-96.

2. Водько, Н. П. Уголовно-правовая борьба с организованной преступностью : научно-практическое пособие / Н. П. Водько. - Москва : Юриспруденция, 2000. - 73 с. - ISBN 5-8401-0026-9.

3. Гладышев, Ю. А. Предупреждение, расследование и раскрытие преступлений, совершаемых иностранными гражданами, и деяний, направленных против них : учебное пособие / Ю. А. Гладышев, Г. Г. Горшенков, С. В. Изосимов, А. П. Кузнецов. - Нижний Новгород : 2000. - С. 6.

4. Государственно-правовые основы миграции населения в Российской Федерации : учебное пособие для студентов вузов, обучающихся по специальности 021100 «Юриспруденция» / [А. С. Прудников и др.] ; под редакцией А. С. Прудникова, М. Л. Тюркина. - Москва : ЮНИТИ: Закон и право, 2006. - 480 с. - ISBN 5-238-01004-4.

5. Доклад Международной конференции по народонаселению и развитию (Каир, сентябрь 1994). - URL: http://www. demoscope.ru/acrobat/icpd_rus.pdf) (дата обращения: 06.07.2020).

6. За справедливый подход к трудящимся-мигрантам в глобальной экономике : доклад на VI Международной конференции труда (92-я сессия, 2004 г.). - Женева, 2004. - 214 р. - ISBN 92-2-413043-7.

7. Загряжская, И. Х. Законодательное регулирование прав мигранта / И. Х. Загряжская. - Москва : Теория будущего, 2002. -C. 12.

8. Ионцев, В. А. Нелегальная миграция в общественно-политическом дискурсе / В. А. Ионцев, И. А. Алешковский // Международная миграция: экономика и политика. - Москва : ТЕИС, 2006. - 130 с.

9. Кузнецова, Н. Ф. Квалификация сложных составов преступлений / Н. Ф. Кузнецова // Уголовное право. - 2000. № 1. - С. 25-32.

10. Миграция, межэтнические отношения, преступность : Сборник научных статей / под редакцией А. П. Кузнецова, Е. А. Логинова. - Н. Новгород. 2005. - С. 126.

11. Пикуров, Н. И. Подлог и другие преступные посягательства на официальный документооборот : учебное пособие / Н. И. Пикуров, Л. А. Букалерова. - Волгоград : Вологоградская академия МВД России, 2001. - 112 c. - ISBN 5-7899-0157-3.

12. Проблема незаконной миграции в России: реалии и поиск решений (по итогам социологического обследования). - Москва, 2004. - С.154.

13. Санташова, Л. Л. Международное сотрудничество в сфере передачи осужденных для отбывания наказания в государства их гражданства / Л. Л. Санташова, А. Л. Санташов. - Москва : Юрлитинформ, 2021. - 164 с. - ISBN 978-5-4396-2142-2.

14. Тепляшин, П. В. Отбывание наказания осужденными иностранными гражданами и лицами без гражданства как предмет уголовно-исполнительного исследования / П. В. Тепляшин, С. М. Мальков // Вестник Кузбасского института. - 2020. - № 2. - С. 190-197.

15. Morehouse, C. Irregular Migration in Europe / Christal Morehouse and Michael Blomfield. - Washington : Migration Policy Institute, 2011. - $18 \mathrm{p}$.

16. Public opinion in the European Union: report. - URL: https://ec.europa.eu/commfrontoffice/publicopinion/archives/ eb/eb78/eb78_publ_en.pdf (дата обращения: 06.07.2020).

\section{REFERENCES}

1. Bobyrev V.V. Topical issues of legal support for countering illegal migration. Pravo i ekonomika=Law and Economics, 2008, no. 1, pp. 92-96. (In Russ.).

2. Vod'ko N.P. Ugolovno-pravovaya bor'ba s organizovannoi prestupnost'yu: nauchno-prakticheskoe posobie [Criminallegal fight against organized crime: scientific and practical guide]. Moscow: Yurisprudentsiya, 2000. 73 p.

3. GladyshevYu.A., Gorshenkov G.G., Izosimov S.V., Kuznetsov A.P. Preduprezhdenie, rassledovanie iraskrytie prestuplenii, sovershaemykh inostrannymi grazhdanami i deyanii, napravlennykh protiv nikh: uchebnoe posobie [Prevention, 
investigation and disclosure of crimes committed by foreign citizens and acts directed against them: a textbook]. Nizhny Novgorod, 2000. P. 6.

4. Prudnikov A.S., Tyurkin M.L. (Eds.). Gosudarstvenno-pravovye osnovy migratsii naseleniya v Rossiiskoi Federatsii: uchebnoe posobie dlya studentov vuzov, obuchayushchikhsya po spetsial'nosti 021100 "Yurisprudentsiya" [State-legal bases of population migration in the Russian Federation: a textbook for university students studying in the specialty 021100 "Jurisprudence"]. Moscow: YuNITI: Zakon i pravo, 2006. 480 p.

5. Report of the International Conference on Population and Development (Cairo, September 1994). Available at: http:// www.demoscope.ru/acrobat/icpd_rus.pdf (accessed July 6, 2020). (In Russ.).

6. Towards a fair deal for migrant workers in the global economy: report of the VI International conference of labor (92nd session, 2004). Geneva, 2004. 214 p. P.11. (In Russ.).

7. Zagryazhskaya I. Kh. Zakonodatel'noe regulirovanie prav migranta [Legislative regulation of the rights of migrants]. Moscow: Teoriya budushchego, 2002. P. 12.

8. Iontsev V.A., Aleshkovskii I.A. Illegal migration in socio-political discourse. In: Mezhdunarodnaya migratsiya: ekonomika i politika [International migration: economics and politics]. Moscow: TEIS, 2006. 130 p. (In Russ.).

9. Kuznetsova N.F. Qualification of complex compositions of crimes. Ugolovnoe pravo=Criminal Law, 2000, no. 1, pp. 2532. (In Russ.).

10. Kuznetsov A.P., Loginov E.A. Migratsiya, mezhetnicheskie otnosheniya, prestupnost': sb. nauch. statei [Migration, interethnic relations, crime: collection of scientific papers]. Nizhny Novgorod, 2005. $126 \mathrm{p}$.

11. Pikurov N.I., Bukalerova L.A. Podlog i drugie prestupnye posyagatel'stva na ofitsial'nyi dokumentooborot: uchebnoe posobie [Forgery and other criminal encroachments on the official document flow: a textbook]. Volgograd: Vologograd. akad. MVD Rossii, 2001. $112 \mathrm{p}$.

12. Problema nezakonnoi migratsii v Rossii: realii i poisk reshenii (po itogam sotsiologicheskogo obsledovaniya) [The problem of illegal migration in Russia: realities and the search for solutions (based on the results of a sociological survey)]. Moscow, 2004. P. 154.

13. Santashova L.L., Santashov A.L. Mezhdunarodnoe sotrudnichestvo v sfere peredachi osuzhdennykh dlya otbyvaniya nakazaniya $v$ gosudarstva ikh grazhdanstva [International cooperation in the field of transfer of convicted persons to the states of their citizenship for serving their sentences]. Moscow: Yurlitinform, 2021. $164 \mathrm{p.}$

14. Teplyashin P.V., Mal'kov S.M. Serving sentences by convicted foreign citizens and stateless persons as a subject of penal research. Vestnik Kuzbasskogo instituta=Bulletin of the Kuzbass Institute, 2020, no. 2, pp. 190-197. (In Russ.).

15. Morehouse C., Blomfield M. Irregular Migration in Europe. Washington: Migration Policy Institute, 2011. 18 p.

16. Public opinion in the European Union: report. Available at: https://ec.europa.eu/commfrontoffice/publicopinion/ archives/eb/eb78/eb78_publ_en.pdf (accessed July 6, 2020).

\section{СВЕДЕНИЯ ОБ АВТOPE / INFORMATION ABOUT THE AUTHOR}

ИГОРЬ ЮРЬЕВИЧ САМОХВАЛОВ - КаНДидаТ Юридических наук, доцент кафедры права, философии и социальных дисциплин факультета экономики и права Арзамасского филиала Национального исследовательского Нижегородского государственного университета им. Н. И. Лобачевского, г. Арзамас, Российская Федерация. ORCID: https://orcid.org/0000-0001-7932-6238, e-mail: herrysam@mail.ru
IGOR' YU. SAMOKHVALOV - Candidate of Sciences (Law), associate professor at the Department of Law, Philosophy and Social Sciences, Faculty of Economics and Law, Arzamas Branch of National Research Lobachevsky State University of Nizhni Novgorod, Arzamas, Russian Federation. ORCID: https://orcid.org/0000-0001-79326238, e-mail: herrysam@mail.ru 